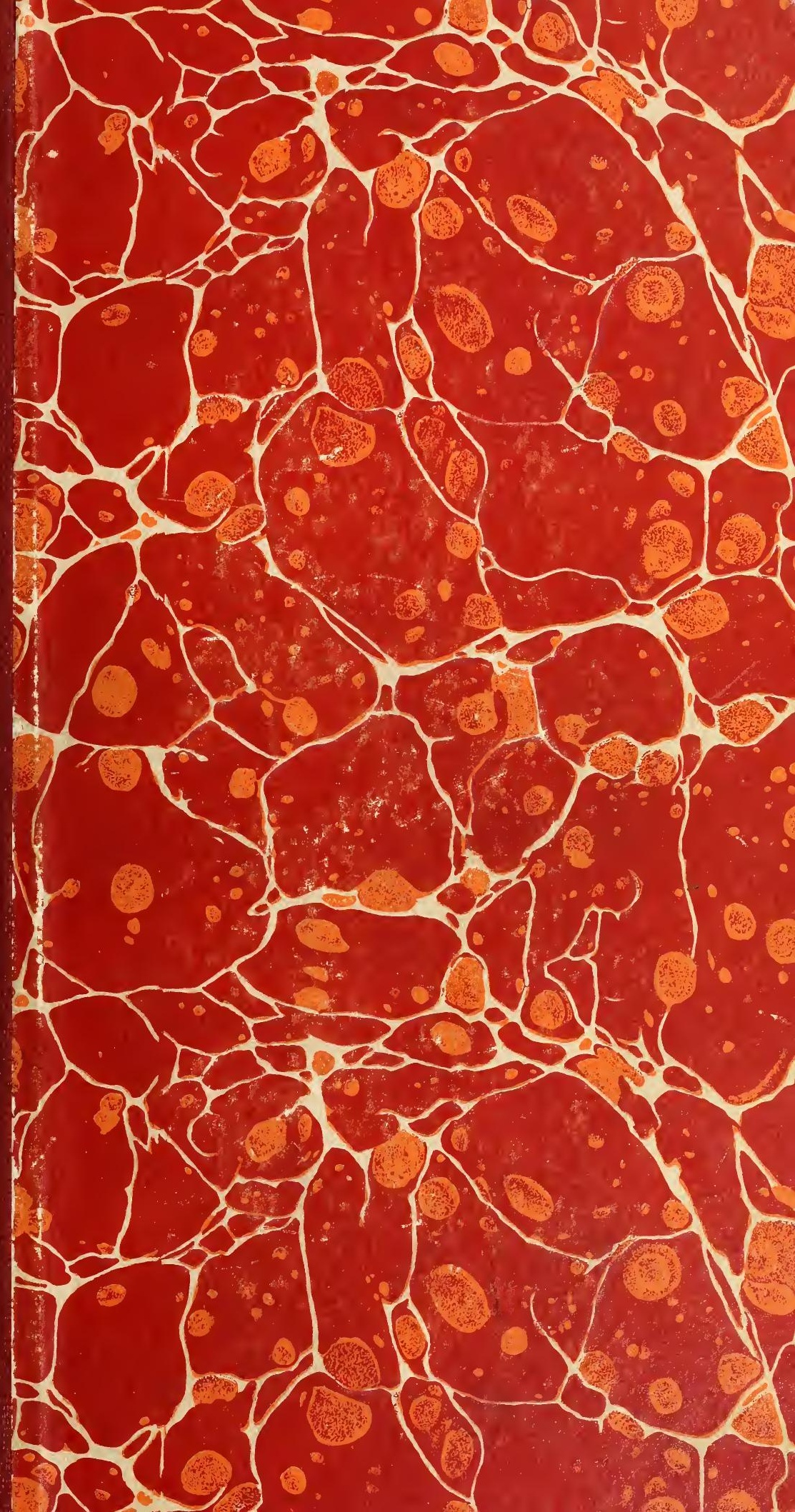



Historic, archived document

Do not assume content reflects current scientific knowledge, policies, or practices. 



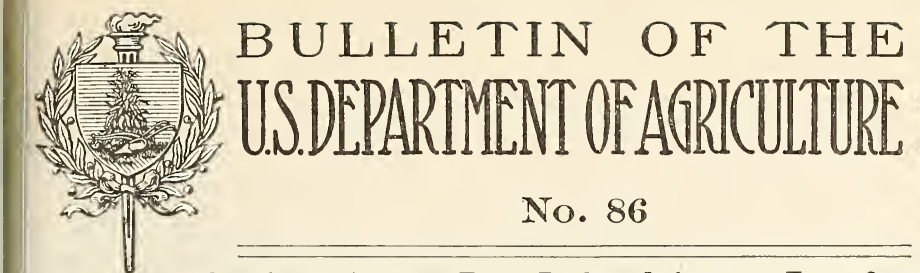

Contribution from the Forest Products Laboratory, Forest Service,

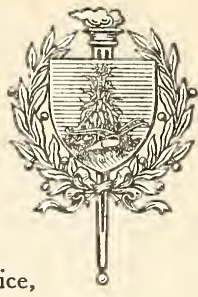

Henry S. Graves, Forester.

March 14, 1914.

(PROFESSIONAL PAPER.)

\title{
TESTS OF WOODEN BARRELS.
}

\author{
By J. A. Newlin, \\ Engineer in Charge of Timber Tests.
}

\section{OBJECT OF THE TESTS.}

The object of the tests described in this bulletin, made in cooperation with the Bureau for the Safe Transportation of Dangerous Explosives, was to obtain data upon which specifications and changes in the design of wooden barrels used in the transportation of dangerous liquids might be based. The tests do not offer any comparisons between barrels made of different material or of different species of timber.

\section{MATERIAL.}

The barrels used in the test were made by the St. Louis Cooperage Co., and were received in six groups of 8 barrels each (48 in all) as follows:

\begin{tabular}{|c|r|r|r|}
\hline $\begin{array}{c}\text { Group } \\
\text { No. }\end{array}$ & Barrel No. & $\begin{array}{c}\text { Thickness } \\
\text { of staves } \\
\text { and heads. }\end{array}$ & $\begin{array}{c}\text { Number } \\
\text { of hoops. }\end{array}$ \\
\hline & & Inches. & \\
1 & 1 to 8 & $5 / 8$ & \\
2 & 1 to to $8 \mathrm{a}$ & $5 / 8$ & 6 \\
3 & 9 to 16 & $3 / 4$ & 6 \\
4 & 9 a to $16 \mathrm{a}$ & $3 / 4$ & 8 \\
5 & 17 to 24 \\
6 & 17 a to $24 \mathrm{a}$ & $7 / 8$ & 6 \\
\hline
\end{tabular}

The barrels were made from quarter-sawed white oak. (One stave which seemed to be particularly porous was identified as red oak.) The material was practically straight grained and free from defects. The barrels were of excellent workmanship and were well coated with paraffin on the inside. The staves varied in width from about $2 \frac{1}{2}$ inches to about 7 inches. Thirty-one barrels had 19 staves each, 12 had 20 each, and 4 had 21 each. The heads were usually

Note.-This bulletin describes tests that are of special interest to barrel manufacturers and to manufacturers and shippers of dangerous liquids. 
composed of four pieces, though two heads were each composed of three pieces. The pieces of the head were joined together with $\frac{5}{16}$-inch hickory dowels. There were two dowels per joint, each about one-third or one-fourth the length of the joint from its end.

The head and bilge hoops were $1 \frac{3}{4}$ inches by 17 gauge, while the quarter hoops were $1 \frac{1}{2}$ inches by 18 gauge. The average thicknesses of hoops used for tension tests (see p. 4) were 0.051 inch and 0.061 inch for the 18 and 17 gauge, respectively, while the U.S. standard gauges of these numbers are 0.05 inch and 0.05625 inch.

The average hoop spacing, dimensions, weights, and capacities of the barrels are shown on figure 1 . The hoop splices were always placed over the bung stave, and the heads were placed with their end grain toward this stave as shown in I and II, figure 1.

The barrels were received at the laboratory on November 24, and were stored in a closed and unheated shed until the tests were begun on December 10.

\section{BARREL TESTS.}

The barrels were brought in from the storage shed shortly before the time for test. Each barrel was then carefully inspected and the hoops driven tight by a representative of the St. Louis Cooperage Co. Just before test each barrel was completely filled with water, and with the exception of those barrels to which a pressure gauge was attached, was closed with a wooden bung. These bungs, after soaking for a few seconds in warm water, were driven to a tight fit. They were placed with their grain parallel to that of the staves. The bungs bore the brand "U. S. Bung Mfg. Co., Cincinnati, O." No bung straps were used.

Two barrels of each group were tested in side compression, two in diagonal compression, one each in side and diagonal drop, and two by internal pressure.

\section{SIDE-COMPRESSION TESTS.}

In this test the barrel was placed between two flat surfaces and compressed in the direction of its diameter. The rate of compression was 0.25 inch per minute. Simultaneous readings of load, compression, and loss of water from the barrel were taken. The test was discontinued when one-half the water had escaped. Notes were made of the character and sequence of failures. In about one-half of these tests a pressure gauge was attached to the barrel, and readings of internal pressure were taken. The method of test is shown in Plate I.

\section{DIAGONAL-COMPRESSION TEST.}

In this test the barrel was compressed between two flat surfaces, being supported upon one point of the chime and loaded at a point on the other and diagonally opposite. The rate of compression was 0.25 inch per minute. Notes were taken as in the side compression test. The test on the first barrel of each group was discontinued as 


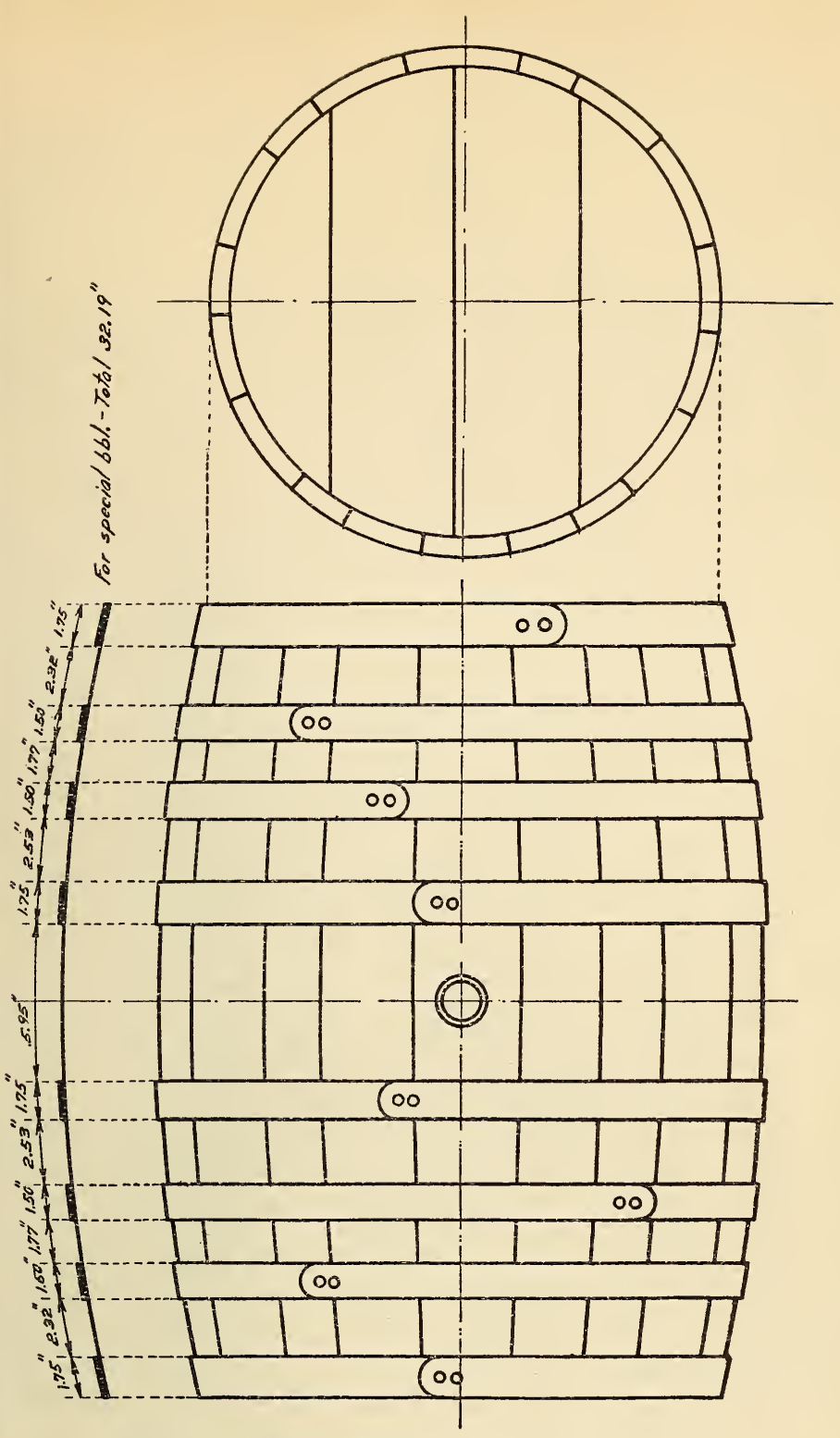

\section{III - MADEUP BARREL - EIGHT HOOPS S\%"STAVES \#" HEAD}

\begin{tabular}{|c|c|c|}
\hline \multirow{2}{*}{$\begin{array}{l}\text { Weight } \\
\text { Pounds }\end{array}$} & \multicolumn{2}{|c|}{ Capacity } \\
\cline { 2 - 3 } & Pounds & Gallons \\
\hline \hline 68.9 & 424.1 & 50.8 \\
\hline
\end{tabular}




in the preceding test, while the second was discontinued whenever one-half the contents had escaped or would have escaped had the barrel been in the reverse position. This test is illustrated in Plate II.

\section{SIDE-DROP TEST.}

In this test the barrels were dropped on a wooden platform about $3 \frac{1}{2}$ inches thick resting on the concrete floor of the laboratory. On top of this platform was a steel plate one-eighth inch in thickness. The barrel was suspended with its axis horizontal. The first drop was 3 inches, the next 6 inches, etc., increasing each tima by 3 inches. Each drop was upon the same point of the barrel. After the first apparent leak the drops were made at 3 -minute intervals. The weight of the barrel and contents was taken immediately before each drop. The test was continued until half the contents of the barrel had escaped. Complete notes were made to show the character and sequence of the failures. A picture of this test is shown in Plate III.

\section{DIAGONAL-DROP TEST.}

This test was conducted in the manner described for the side-drop test, except that the barrel was suspended so that the lowest point of the chime was directly below the center of the barrel, which was dropped on the chime. Each drop was upon the same point. A picture of this test is shown in Plate IV.

\section{INTERNAL-PRESSURE TEST.}

In this test the barrel and connecting pipes were filled with water in such a way as to exclude as nearly as possible all air. The pressure was then raised to 2 pounds per square inch and held for 2 minutes. It was then raised to 4 pounds and there held for 2 minutes. This was repeated, increasing the pressure 2 pounds each time and holding it constant for 2 minutes after each increase, until 1 pound of water ran from the barrel in 1 minute or less. The test was then discontinued. Complete notes were made as to the character and sequence of the failures.

In these tests connection to the barrel was made by screwing a special tapered bush into the bunghole. The apparatus is shown in Plate V.

\section{MINOR TESTS.}

STAVE TESTS.

In order to find out something of the variability of the barrel material tests were made on 36 staves, two from each of 6 barrels of each thickness. The best and poorest appearing stave of each barrel was chosen. Pieces 2 inches in width, cut from these staves, were tested in static bending under center loading. The span was 28 inches. The staves were placed with the outer side up. 


\section{HOOP TESTS.}

A 14-inch piece was taken from one hoop of each gauge from each of three barrels of each group. These pieces were machined down to have a parallel section approximately 1 inch by 9 inches, and were then subjected to tension tests. The maximum load and load at yield point, as determined from the drop of the scale beam of the testing machine, were recorded.

\section{RESULTS.}

\section{BARREL TESTS.}

The results of the barrel tests are given in Tables 3 to 6 , inclusive.

The internal-pressure readings on the barrels to which a pressure gauge was attached in the side-compression test have been omitted. The highest internal pressure developed in these barrels was 7 pounds per square inch.

In all the test only two or three cases of leakage at the bung was observed. These also have been omitted from the tabulated results.

\section{MINOR TESTS.}

The average, maximum, and minimum results of the stave and hoop tests are given in Tables 1 and 2. In Table 1 "modulus of rupture" is the fiber stress at maximum load and represents the strength of the timber. "Work to maximum load" is proportional to the shockresisting ability of the timber.

TABLE 1.-Results of stave tests. Static bending, 28-inch span.

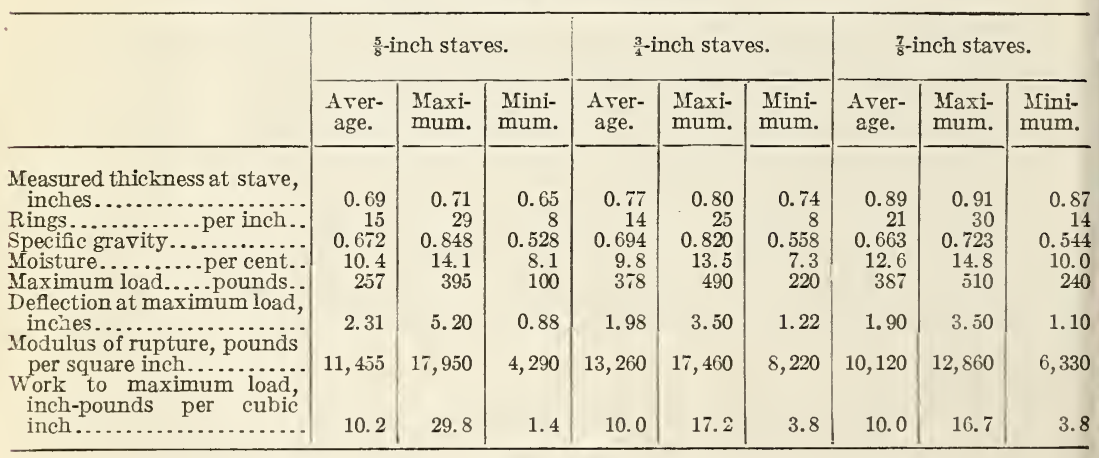

TABle 2.-Results of hoop tests. Tension, specimens 1 inch wide.

\begin{tabular}{|c|c|c|c|c|c|c|}
\hline & \multicolumn{3}{|c|}{ 18-gauge hoops. } & \multicolumn{3}{|c|}{ 17-gauge hoops. } \\
\hline & A verage. & Maximum. & Minimum. & Average. & Maximum. & Minimum. \\
\hline $\begin{array}{l}\text { Measured thickness of hoops, } \\
\text { inches............................... }\end{array}$ & 0.051 & 0.058 & 0.047 & 0.061 & 0.063 & 0.058 \\
\hline $\begin{array}{l}\text { Loadat yield point as determined } \\
\text { by drop of beam } \ldots \ldots \text { pounds.. } \\
\text { Maximum load } . . . . . . . .\end{array}$ & $\begin{array}{l}2,360 \\
3,955\end{array}$ & $\begin{array}{l}2,900 \\
4,530\end{array}$ & $\begin{array}{l}2,100 \\
3,580\end{array}$ & $\begin{array}{l}2,480 \\
4,925\end{array}$ & $\begin{array}{l}2,620 \\
5,130\end{array}$ & $\begin{array}{l}2,330 \\
4,605\end{array}$ \\
\hline $\begin{array}{l}\text { Fiber stress at yield point, pounds } \\
\text { per square inch......................... }\end{array}$ & 44,580 & 49,500 & 41,200 & 39,515 & 42,400 & 36,000 \\
\hline $\begin{array}{l}\text { Fiber stress at maximum load, } \\
\text { pounds per square inch.......... }\end{array}$ & & 78,600 & 70,200 & 78,060 & 82,400 & 71,600 \\
\hline
\end{tabular}




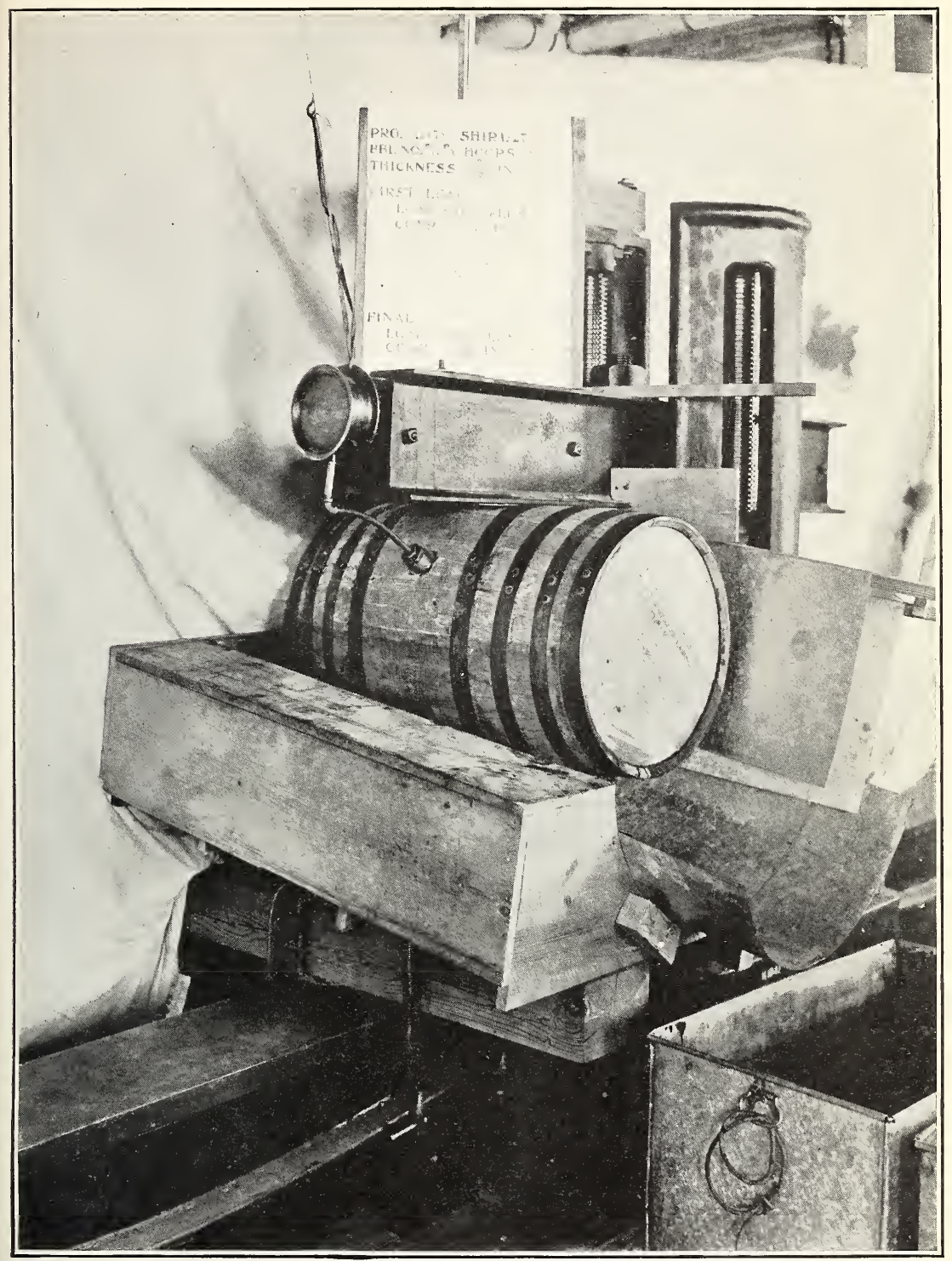

METHOD OF TEST-SIDE COMPRESSION. 


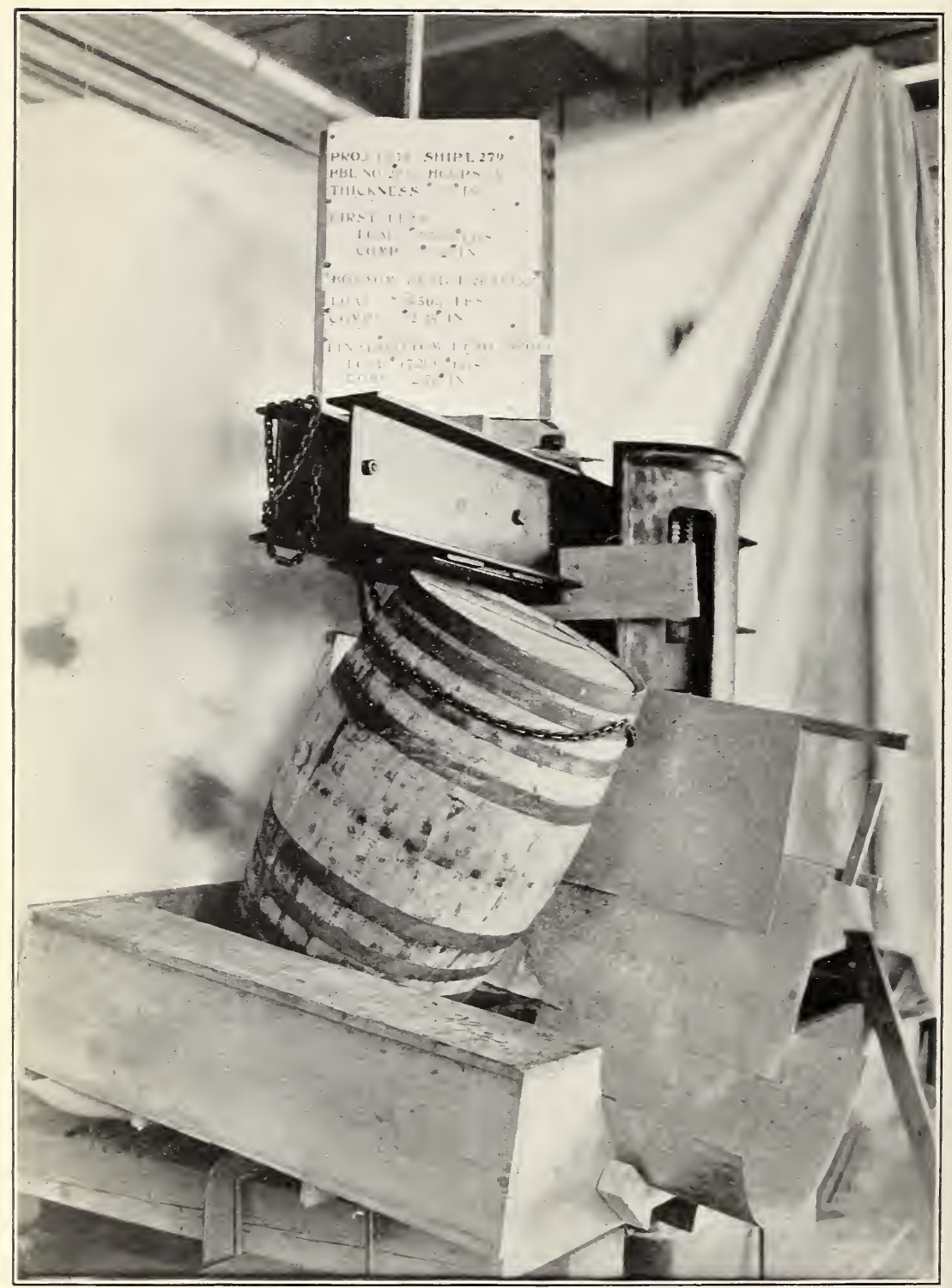

METHOD OF TEST-Diagonal COMPREssion. 


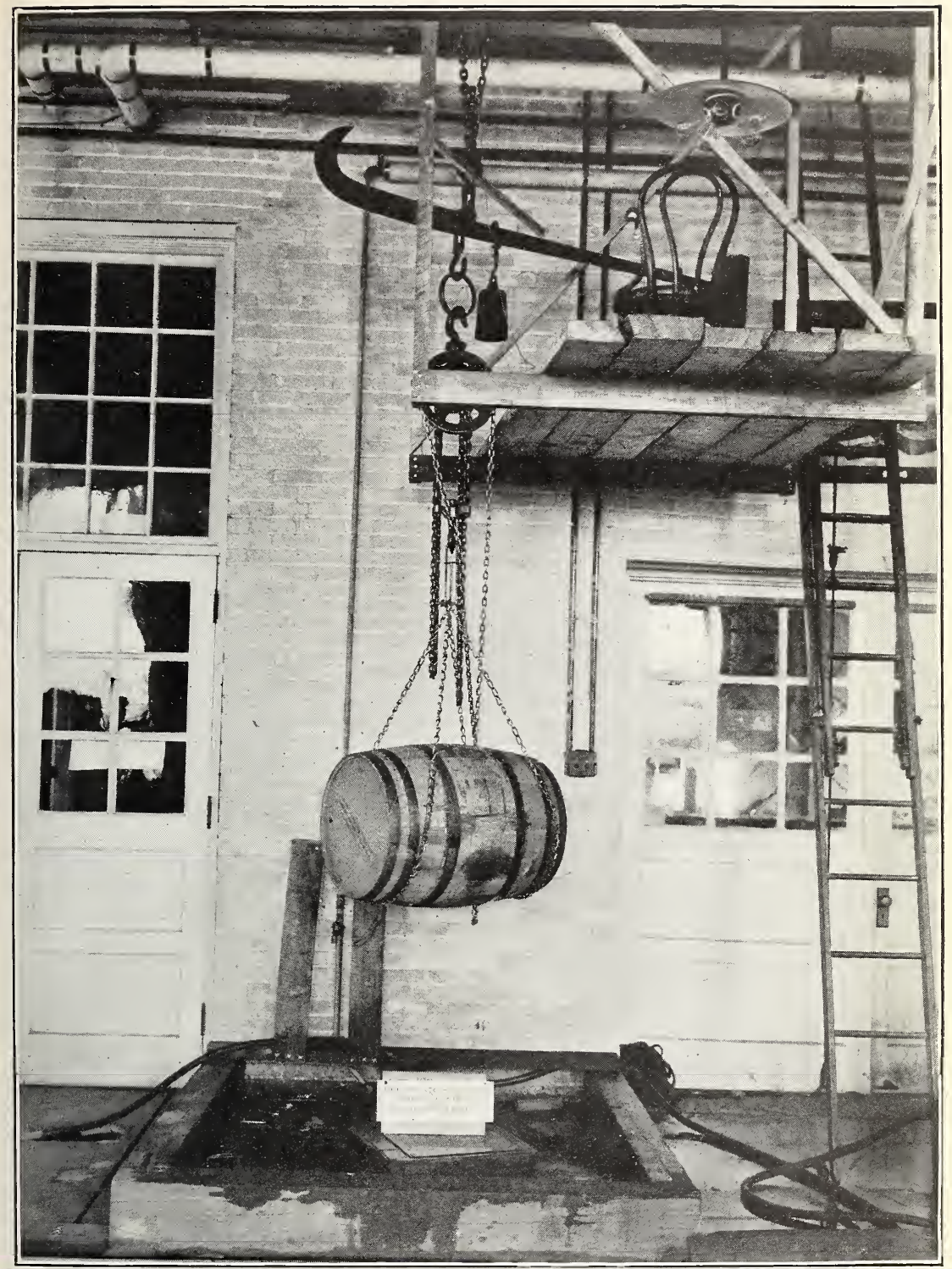

METHOD OF TEST-SIDE DROP. 


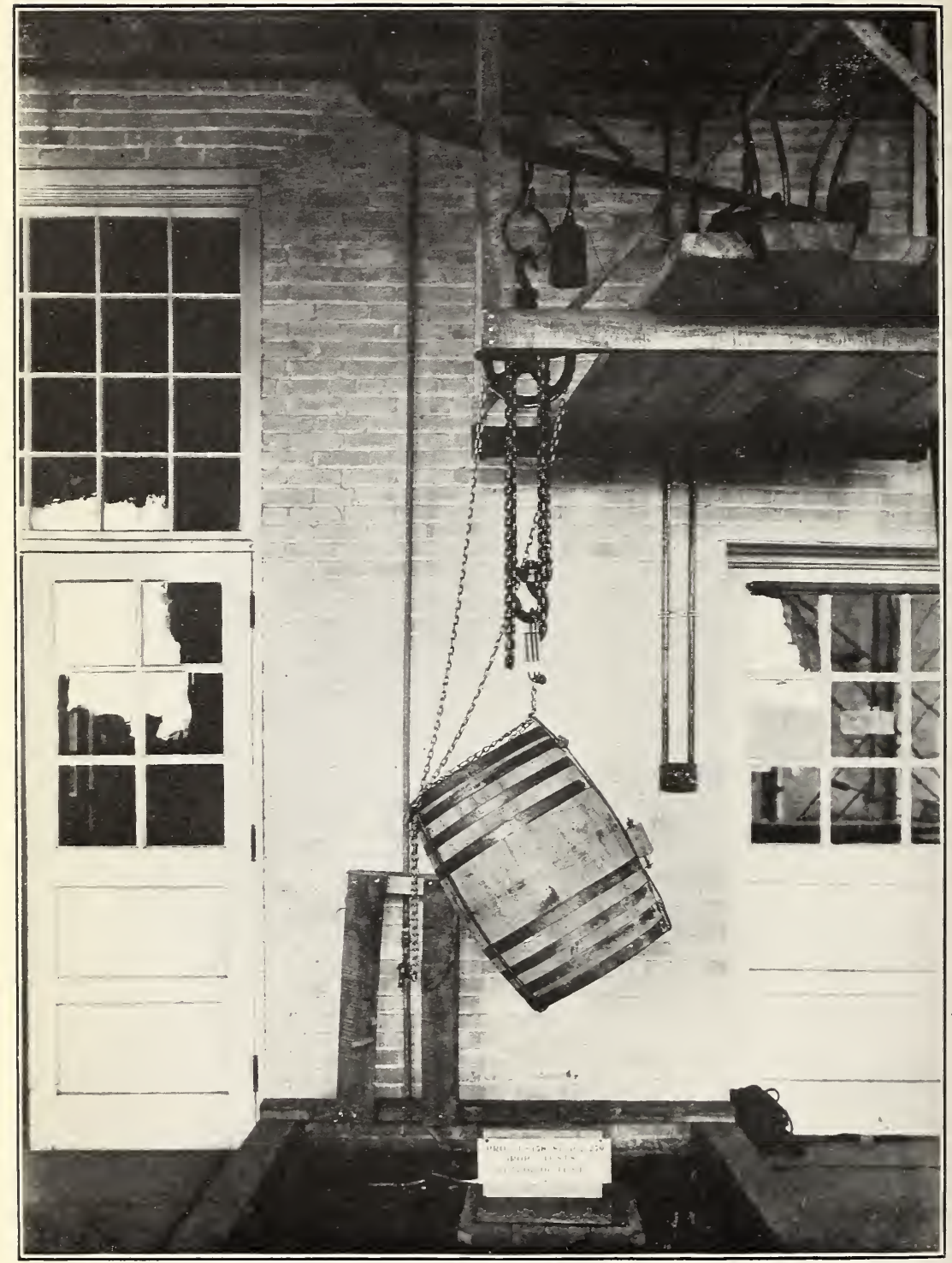

METHOD OF TEST-DIAGONAL DROP. 


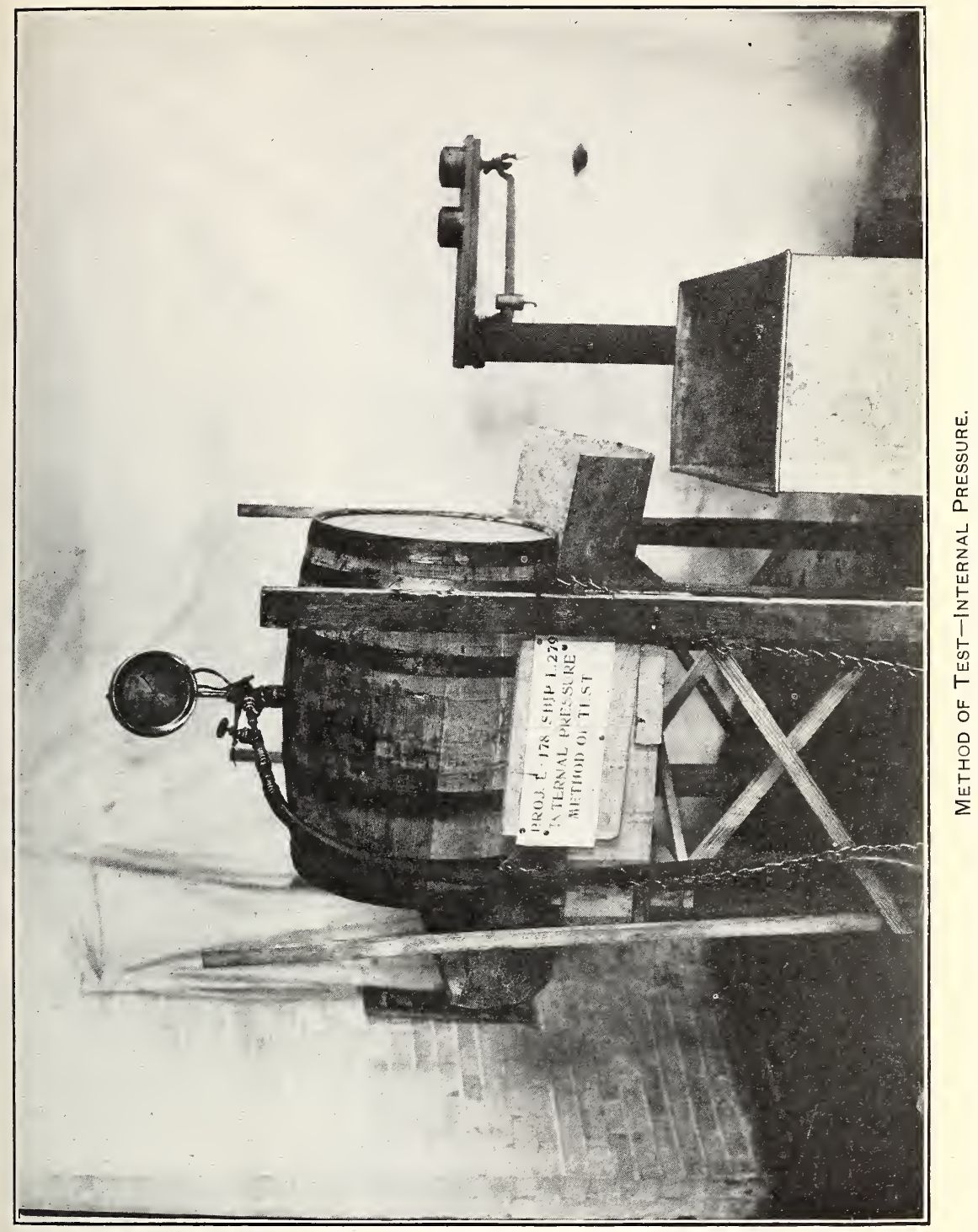





\section{GENERAL OBSERVATIONS OF NATURE OF FAILURES.}

In each kind of test the first water to appear on the outside of the barrel was usually from the seepage through the pores of the wood at the chime. The first leak usually occurred either between the staves and the head or between the staves at the chime. In all the tests except the internal pressure the first leak was usually coincident with the slipping of the staves.

In the internal-pressure test there were two general classes of failures: (1) By springing and breaking of the head; and (2) by leaking between the staves at the bilge.

In the diagonal-compression test the failure was a general failure of the head combined with the slipping of the staves. In the com pression-perpendicular test the failure was a general leaking at the heads and slipping of the staves followed by the breaking of the staves at the bilge.

In the side-drop test the slipping of the staves caused loosening of the hoops and leakage at the heads. This was followed by breaking of the staves at the bilge. In three of the six tests the failure of the barrels was due to the heads being broken or forced out by the internal pressure produced by the impact.

The lower heads of all barrels tested by dropping on the chime were broken or forced out by the pressure due to the impact.

\section{CHANGES IN DESIGN AS INDICATED BY THE CHARACTER OF THE FAILURES.}

A slight increase in the length of the chime from croze to the end of the stave would lessen the amount of seepage without any marked increase of liability to breakage at the croze by dropping the barrel on the chime. The chimes of the test barrels were made exceptionally short (three-fourths of an inch from outer side of croze to end of stave) to reduce the danger of breakage when dropped on the chime. Chimes 1 inch long would probably have given better results.

The internal-pressure test and the side-drop test indicated that the bilge hoops were too wide apart. A spacing of not more than 8 inches between the bilge hoops would have materially strengthened the barrels for the internal pressure without any weakening for the other tests.

The weakest parts of the barrels were the heads. The first leak in most of the tests was due either to the springing of the head or to the slipping of the staves at the head, or to both these causes.

The ultimate failure of a large per cent of the barrels was at the head. It appears that a head much thicker than the staves would give materially better results. Heads should probably be made about one and one-half times as thick as the staves.

The heads appeared to be materially weakened by the dowel holes and not infrequently the flagging was forced out. It would seem that these head joints could be improved. 
None of the hoops failed during the test. A $\frac{7}{8}$-inch oak barrel should probably have not less then eight hoops of the sizes of those used on the barrels tested, as the swelling of the wood might break the hoops.

Variation in strength of barrels of the same design is due in large measure to the variability of the wood composing the head and staves. Test specimens taken from these barrels show that some of the staves may have less than one-fourth the strength of others. (See Table 1, p. 4.) Evidently no attempt had been made to grade the staves on the basis of strength, the only criterion of fitness being that the staves should be clear and straight grained. The dry weight per cubic foot of clear straight-grained wood is a splendid guide as to probable strength, the heavier, denser wood being the stronger. The advisability of grading staves and heading with reference to the strength might well be considered.

\section{TESTS OF MADE-UP BARRELS.}

BARRELS.

In order to try out the effect of some of the changes in design as suggested above, barrels were made up with $\frac{5}{8}$-inch staves, $\frac{7}{8}$-inch head, and eight hoops. The staves and hoops were from the two 8-hoop, $\frac{5}{8}$-inch barrels, the heads from $\frac{7}{8}$-inch barrels and previously tested under internal pressure. In order to make these heads fit, it was necessary to joint fifteen-sixteenths inch off of one stare of each barrel. The bilge and quarter hoops were not changed, but were permitted to drive farther onto the barrels. The head hoops were shortened $1 \frac{1}{2}$ inches and were driven flush with the ends of the staves. (In the original tests the head hoops were driven beyond the ends of the staves, as shown in I and II of fig. 1.) The spacing of the hoops, weight, capacity, etc., of these barrels are shown in III, figure 1 . In assembling the barrels the hoop joints were placed at random.

INTERNAL-PRESSURE TESTS.

The two made-up barrels were tested under internal pressure. The results of these tests showed them to be fully equal to the barrels with $\frac{7}{8}$-inch heads and staves. One of these barrels withstood a pressure of 34 pounds per square inch up to the time the head began to fail, when the pressure was released. The increased capacity of the barrel under this pressure, due primarily to the springing of the heads, was $8 \frac{1}{4}$ pounds of water. On release of the pressure the barrel resumed its original form with no apparent leakage.

The head of the second barrel was broken out by a pressure of 38 pounds per square inch.

Neither of these made-up barrels showed any.leakage between the staves during the tests. 
DROP TESTS.

The broken heads of the made-up barrels were replaced by other $\frac{7}{8}$-inch heads, and the barrels subjected to drop tests. The barrel dropped upon the side showed much better resistance than the 8-hoop barrel five-eighths inch in thickness throughout, but was not quite the equal of the $\frac{7}{8}$-inch barrels.

In dropping on the chime the made-up barrel was the equal of any barrel tested.

These tests of made-up barrels seem to justify the previously suggested changes in thickness of head and spacing of hoops.

The detailed results of these tests are given in Table 5.

\section{SUGGESTIONS REGARDING TESTS OF SHIPPING CONTAINERS.}

There are two classes of tests to which containers such as barrels may be subjected:

First. Tests, such as the ones described in this bulletin, where the object is to determine the most economical and efficient designs. Tests of this class are usually carried to the destruction of the container and entail damage or complete loss of contents. It is necessary to fill the containers with material which is relatively inexpensive, safe to the investigators, and which will produce stresses similar in character to those which would be produced by the commodity which the container is intended to carry.

Second. Tests to determine the suitability of the container for specified commodities under practical conditions. Such tests should be made upon containers filled with the material to be shipped in them or with some other very similar in its action on the container.

In the case of the first class of tests seepage through the pores and the first leak depend largely upon the nature of the lining and of the contained liquid. A material difference might be expected in the behavior of barrels lined with paraffin and filled with water as compared with barrels lined with glue and filled with gasoline. In the drop test the height of drop also depends upon the specific gravity of the contained liquid. The height of drop required to produce given stresses is in approximately inverse proportion to the combined weight of barrel and contents.

Having made tests of the first class, and so determined the best construction, it then remains to manufacture containers in accordance with specifications based upon the results of these tests. Tests of the second class made upon such containers lined according to commercial practice and filled with the commodity they are to carry would show their limitations under practical conditions.

In the case of barrels internal-pressure and side-drop tests are recommended for this purpose. 
TABLE 3.-Individual tests-Side compression.

$\frac{5}{8}$ INCH BARRELS.

\begin{tabular}{|c|c|c|c|c|c|}
\hline $\begin{array}{c}\text { No. } \\
\text { of } \\
\text { barrel. }\end{array}$ & $\begin{array}{l}\text { Num- } \\
\text { ber of } \\
\text { hoops. }\end{array}$ & $\begin{array}{c}\text { Deflec- } \\
\text { tion. }\end{array}$ & Load. & $\begin{array}{c}\text { Rate } \\
\text { of } \\
\text { leaking. }\end{array}$ & Remarks. \\
\hline 1a & 8 & $\begin{array}{l}0.81 \\
1.12 \\
1.24 \\
2.35 \\
3.80 \\
5.38 \\
6.35 \\
.88 \\
1.20 \\
2.54 \\
5.97 \\
.85 \\
1.08 \\
2.80 \\
3.80 \\
4.37 \\
5.40 \\
5.70 \\
.60 \\
.64 \\
1.55 \\
3.80 \\
4.62 \\
7.11 \\
7.61\end{array}$ & $\begin{array}{r}5,000 \\
6,000 \\
6,340 \\
8,920 \\
11,000 \\
14,380 \\
13,640 \\
5,000 \\
6,000 \\
8,500 \\
10,850 \\
5,500 \\
6,500 \\
9,460 \\
11,250 \\
11,000 \\
12,310 \\
11,880 \\
4,500 \\
4,750 \\
7,500 \\
12,320 \\
12,070 \\
15,040 \\
15,370\end{array}$ & 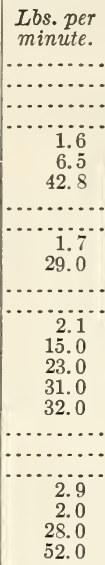 & $\begin{array}{l}\text { Seepage through pores. } \\
\text { Staves slip. } \\
\text { Leak between staves. } \\
\text { Stare broke. } \\
\text { Horizontal shear in top stave. } \\
\text { Stave broke. } \\
\text { One-half contents escaped. } \\
\text { Leak at chime. } \\
\text { Stave slipped. } \\
\text { Stare sheared. } \\
\text { One-half contents escaped. } \\
\text { Leak between staves. } \\
\text { Staves slip. } \\
\text { Bottom stave sheared. } \\
\text { Stave split. } \\
\text { Stave broke. } \\
\text { Do. } \\
\text { One-half contents escaped. } \\
\text { Seepage through pores. } \\
\text { Leakage around end at bottom. } \\
\text { Staves slip. } \\
\text { Stare broke. } \\
\text { Bottom stave broke. } \\
\text { Stave broke. } \\
\text { One-half contents escaped. }\end{array}$ \\
\hline
\end{tabular}

$\frac{3}{4}$-INCH BARRELS.

\begin{tabular}{|c|c|c|c|c|c|}
\hline $10 \mathrm{a}$ & 8 & $\begin{array}{r}0.57 \\
.77 \\
.86 \\
2.35 \\
3.36 \\
3.75 \\
.77 \\
.90 \\
1.24 \\
2.88 \\
4.00 \\
4.30 \\
.64 \\
.86 \\
1.15 \\
3.60 \\
4.35 \\
4.53 \\
.57 \\
1.03 \\
1.70 \\
3.80\end{array}$ & $\begin{array}{r}5,000 \\
6,000 \\
6,500 \\
9,730 \\
10,830 \\
11,380 \\
5,500 \\
6,000 \\
7,000 \\
10,910 \\
11,110 \\
10,420 \\
5,500 \\
6,500 \\
8,000 \\
11,590 \\
12,430 \\
12,390 \\
5,000 \\
7,000 \\
8,860 \\
12,010\end{array}$ & 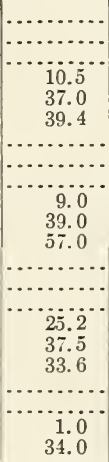 & $\begin{array}{l}\text { Leak at chime. } \\
\text { Seepage through pores. } \\
\text { Staves slip. } \\
\text { Stave broke. } \\
\text { Do. } \\
\text { One-half contents escaped. } \\
\text { Seepage through pores. } \\
\text { Staves slip. } \\
\text { Leak between stares and at chimes. } \\
\text { Bottom stave broke. } \\
\text { Increased breaking. } \\
\text { One-half contents escaped. } \\
\text { Leak between staves. } \\
\text { Leak at chime. } \\
\text { Staves slip. } \\
\text { Top stave sheared. } \\
\text { Bottom stave broke. } \\
\text { One-half contents escaped. } \\
\text { Leak at chime. } \\
\text { Stares slip. } \\
\text { Leak between staves. } \\
\text { One-half contents escaped. }\end{array}$ \\
\hline
\end{tabular}

7-INCH BARRELS.

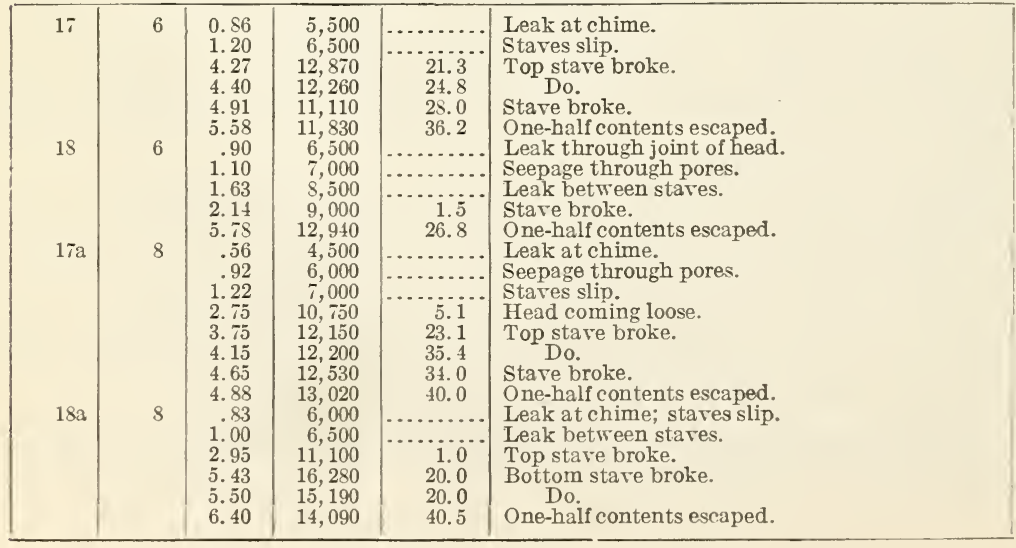


TABLE 4.-Individual tests-Diagonal compression.

5-INCH BARRELS.

\begin{tabular}{|c|c|c|c|c|c|}
\hline $\begin{array}{c}\text { No. } \\
\text { of } \\
\text { barrel. }\end{array}$ & $\begin{array}{l}\text { Num- } \\
\text { ber of } \\
\text { hoops. }\end{array}$ & $\begin{array}{l}\text { Deflec- } \\
\text { tion. }\end{array}$ & Load. & $\begin{array}{c}\text { Rate } \\
\text { of } \\
\text { leaking. }\end{array}$ & Remarks. \\
\hline $\begin{array}{c}4 \\
3 a\end{array}$ & 8 & $\begin{array}{l}0.56 \\
1.45 \\
3.40 \\
3.56 \\
.77 \\
3.78 \\
4.48 \\
.85 \\
1.38 \\
1.55 \\
2.26 \\
2.85 \\
.97 \\
1.73 \\
2.50\end{array}$ & $\begin{array}{r}7,000 \\
11,000 \\
15,620 \\
10,020 \\
8,000 \\
16,240 \\
16,990 \\
8,500 \\
13,000 \\
14,000 \\
16,400 \\
15,000 \\
8,500 \\
14,480 \\
15,440\end{array}$ & 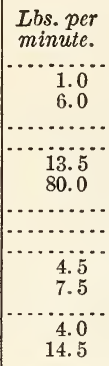 & $\begin{array}{l}\text { Leak at chime. } \\
\text { Staves sheared. } \\
\text { Bottom head broke. } \\
\text { One-half contents escaped. } \\
\text { Leak at chime; staves slipping. } \\
\text { Bottom head broke. } \\
\text { One-half contents escaped. } \\
\text { Leak at bottom chime. } \\
\text { Leak at top chime. } \\
\text { Staves slipping. } \\
\text { Top head breaking. } \\
\text { Top head broke. } \\
\text { Leaks at top and bottom chimes. } \\
\text { Staves slip; bottom head breaking. } \\
\text { Bottom head broke. }\end{array}$ \\
\hline
\end{tabular}

$\frac{3}{4}$-INCH BARRELS.

\begin{tabular}{|c|c|c|c|c|c|}
\hline $11 \mathrm{a}$ & 8 & $\begin{array}{l}0.62 \\
1.18 \\
1.50 \\
5.73 \\
8.42 \\
.90 \\
1.26 \\
1.50 \\
3.20 \\
.58 \\
1.48 \\
2.10 \\
.75 \\
1.53 \\
2.47 \\
9.25\end{array}$ & $\begin{array}{r}7,500 \\
11,000 \\
12,460 \\
17,000 \\
17,850 \\
9,000 \\
11,500 \\
12,500 \\
16,530 \\
8,000 \\
14,500 \\
16,000 \\
8,000 \\
14,000 \\
16,970 \\
24,260\end{array}$ & 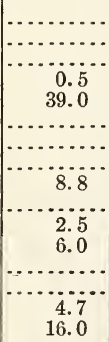 & $\begin{array}{l}\text { Leak at chime. } \\
\text { Leak at bearing. } \\
\text { Top head broke; staves sheared. } \\
\text { Staves breaking at top. } \\
\text { One-half contents escaped. } \\
\text { Leak at bottom stave. } \\
\text { Stave splitting at top. } \\
\text { Leak at bottom chime. } \\
\text { Bottom head broke. } \\
\text { Leak at bottom chime. } \\
\text { Staves slipping. } \\
\text { Top head broke. } \\
\text { Leak at top chime. } \\
\text { Staves slipping. } \\
\text { Top head broke. } \\
\text { Test discontinued. }\end{array}$ \\
\hline
\end{tabular}

7-INCH BARRELS.

\begin{tabular}{|c|c|c|c|c|c|}
\hline $19 \mathrm{a}$ & 8 & $\begin{array}{r}0.42 \\
.77 \\
1.68 \\
3.73 \\
5.50 \\
7.47 \\
.81 \\
1.12 \\
2.34 \\
4.20 \\
5.00 \\
.62 \\
1.43 \\
3.83 \\
4.85 \\
5.05 \\
.32 \\
.95 \\
1.27 \\
2.35 \\
2.70\end{array}$ & $\begin{array}{r}6,500 \\
8,500 \\
11,500 \\
17,660 \\
18,000 \\
11,540 \\
9,500 \\
10,500 \\
14,560 \\
19,280 \\
20,530 \\
8,000 \\
13,000 \\
19,790 \\
21,740 \\
21,650 \\
11,000 \\
11,500 \\
12,500 \\
16,500 \\
17,200\end{array}$ & 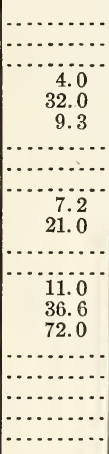 & $\begin{array}{l}\text { Leak at bottom chime. } \\
\text { Staves slipping. } \\
\text { Leak at top chime. } \\
\text { Top head splitting. } \\
\text { Top head broke. } \\
\text { One-half contents escaped. } \\
\text { Leak at bottom chime; staves slipping. } \\
\text { Leak between staves at bottom. } \\
\text { Staves slipping. } \\
\text { Top head breaking. } \\
\text { Top head broke. } \\
\text { Leak at bottom chime. } \\
\text { Staves slipping. } \\
\text { Staves sheared at chime. } \\
\text { Top head broke. } \\
\text { One-half contents escaped. } \\
\text { Leak at bottom chime. } \\
\text { Staves slipping. } \\
\text { Leak at top chime. } \\
\text { Bottom head breaking. } \\
\text { Bottom head broke. }\end{array}$ \\
\hline
\end{tabular}




\section{TABLE 5.-Individual tests-Drop tests. \\ S-INCH BARRELS.}

\begin{tabular}{|c|c|c|c|c|c|}
\hline $\begin{array}{l}\text { No. of } \\
\text { barrel. }\end{array}$ & $\begin{array}{l}\text { Num- } \\
\text { ber of } \\
\text { hoops. }\end{array}$ & $\begin{array}{l}\text { Height } \\
\text { of drop. }\end{array}$ & $\begin{array}{l}\text { Rate of } \\
\text { leakage. }\end{array}$ & \multicolumn{2}{|l|}{ Remarks. } \\
\hline \multicolumn{6}{|c|}{ SIDE DROP. } \\
\hline $5 \mathrm{a}$ & 8 & $\begin{array}{c}\text { Inches. } \\
6 \\
12 \\
18 \\
24 \\
30 \\
6 \\
9 \\
12 \\
24 \\
27\end{array}$ & 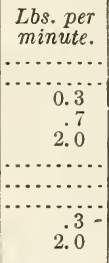 & $\begin{array}{l}\text { Stave slipped; leak at chimes. } \\
\text { Leak between staves. } \\
\text { Stave cracked. } \\
\text { Head cracked; hoops slipped at head. } \\
\text { Head broke out. } \\
\text { Leak at chime and between staves. } \\
\text { Staves slipping. } \\
\text { Stave broke. } \\
\text { Flag coming out at head. } \\
\text { Head broke out; split at dowels. }\end{array}$ & - \\
\hline \multicolumn{6}{|c|}{ DIAGONAL DROP. } \\
\hline $\begin{array}{l}6 \\
6 \mathrm{a}\end{array}$ & 6 & $\begin{array}{r}9 \\
12 \\
9\end{array}$ & & $\begin{array}{l}\text { Leak at chime. } \\
\text { Head broke. } \\
\text { Head broke out. }\end{array}$ & \\
\hline
\end{tabular}

\section{3-INCH BARRELS.}

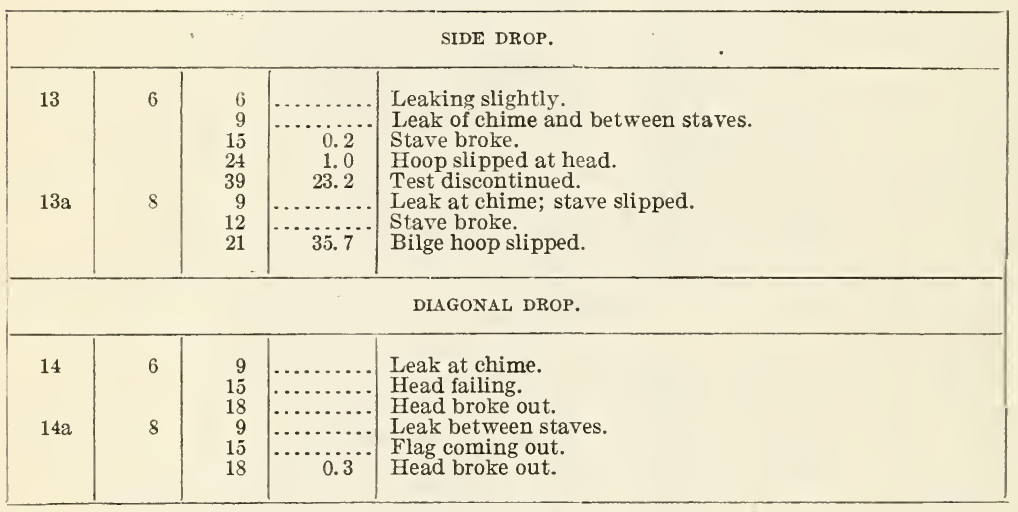

\section{7.-NCH BARRELS.}

\begin{tabular}{|c|c|c|c|c|}
\hline 21 & 8 & $\begin{array}{r}9 \\
21 \\
24 \\
27 \\
48 \\
9 \\
21 \\
33 \\
36\end{array}$ & \begin{tabular}{r|}
$\cdots$ \\
$\cdots \cdots$ \\
2.0 \\
11.3 \\
$\cdots \cdots+$. \\
.3 \\
.7
\end{tabular} & $\begin{array}{l}\text { Leaks at chimes; staves slipped. } \\
\text { Stave broke. } \\
\text { Bilge hoop slips. } \\
\text { Head hoop slipped. } \\
\text { Test discontinued. } \\
\text { Stave slips. } \\
\text { Leak at chime. } \\
\text { Head broke. } \\
\text { Head broke out. }\end{array}$ \\
\hline \multicolumn{5}{|r|}{ DLAGONAL DROP. } \\
\hline $22 \mathrm{a}$ & 6 & $\begin{array}{r}6 \\
12 \\
15 \\
21 \\
15 \\
18\end{array}$ & $\begin{array}{r}0.7 \\
.3 \\
.6 \\
.4\end{array}$ & $\begin{array}{l}\text { Leak at chime. } \\
\text { Stave sheared. } \\
\text { Leak through joint of head. } \\
\text { Head broke out. } \\
\text { Head breaking. } \\
\text { Head broke out. }\end{array}$ \\
\hline
\end{tabular}


TABLE 6.-Individual tests-Internal pressure.

ह8-INCH BARRELS.

\begin{tabular}{|c|c|c|c|c|c|}
\hline $\begin{array}{l}\text { No. of } \\
\text { barrel. }\end{array}$ & Num- & $\begin{array}{l}\text { Pres- } \\
\text { sure. }\end{array}$ & Rate of & leakage. & Remarks. \\
\hline $8 a$ & 8 & $\begin{array}{c}\text { Lbs. per } \\
\text { sq. inch. } \\
2 \\
4 \\
8 \\
10 \\
12 \\
2 \\
4 \\
6 \\
8 \\
10 \\
12 \\
13 \\
4 \\
8 \\
10 \\
16 \\
2 \\
4 \\
8 \\
12 \\
14\end{array}$ & 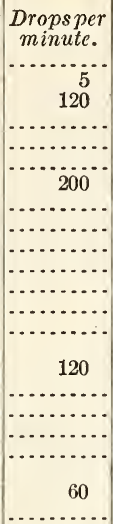 & $\begin{array}{c}\text { Lbs. per } \\
\text { minute. }\end{array}$ & $\begin{array}{l}\text { Seepage through pores. } \\
\text { Leak between staves. } \\
\text { Head bulged flush with chime. } \\
\text { Leak at chime; broken stream. } \\
\text { Leak between staves. } \\
\text { Leak at chime. } \\
\text { Leak between staves at oilge. } \\
\text { Heads bulged flush with chimes. } \\
\text { Seeping in stream through pores. } \\
\text { Leak through joints of head. } \\
\text { Displacement of flag. } \\
\text { Seepage through pores. } \\
\text { Leak at chimes and head bulged fiush with } \\
\text { chime. } \\
\text { Leak through joints at end. } \\
\text { Flag forced out. } \\
\text { Seepage through pores. } \\
\text { Leak between staves at end. } \\
\text { Head bulged flush with chime; leak between } \\
\text { staves at bilge and through joints in head. } \\
\text { Leak in head. }\end{array}$ \\
\hline
\end{tabular}

3-INCH BARRELS.

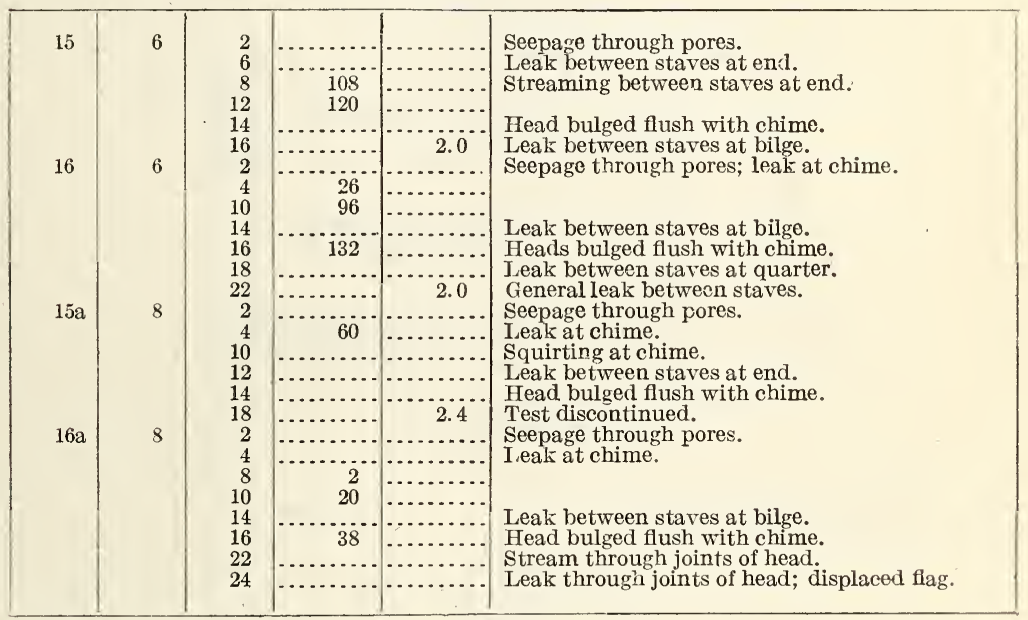

7

\begin{tabular}{|c|c|c|c|c|c|}
\hline 24 & 6 & $\begin{array}{r}4 \\
8 \\
12 \\
14 \\
18 \\
20 \\
24 \\
4 \\
10 \\
12 \\
14 \\
18 \\
20 \\
28\end{array}$ & 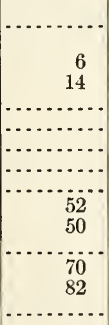 & 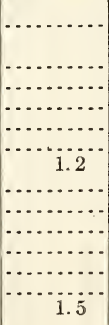 & $\begin{array}{l}\text { Leak at chime and at flag; seepage through } \\
\text { pores. } \\
\text { Leak between staves at bilge. } \\
\text { Head bulged flush with chime. } \\
\text { Leak at joint of head. } \\
\text { Leak between staves. } \\
\text { Seepage through pores; leak at chime. } \\
\text { Leak between staves at quarter. } \\
\text { Leak between staves at bilge. } \\
\text { Head bulged flush with chime. } \\
\text { Leak at joints of head. } \\
\text { Leak between staves. }\end{array}$ \\
\hline
\end{tabular}


TABLE 6.-Individual tests-Internal pressure-Continued.

5-INCH BARRELS-Continued.

\begin{tabular}{|c|c|c|c|c|c|}
\hline $\begin{array}{l}\text { No. of } \\
\text { barrel. }\end{array}$ & Num- & $\begin{array}{l}\text { Pres- } \\
\text { sure: }\end{array}$ & Rate of & leakage. & Remarks. \\
\hline $23 a$ & 8 & $\begin{array}{c}\text { Lbs. per } \\
\text { sq.inch. } \\
6 \\
12 \\
16 \\
20 \\
30 \\
4 \\
8 \\
16 \\
18 \\
22 \\
24 \\
30 \\
36 \\
38\end{array}$ & 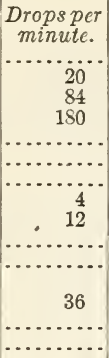 & 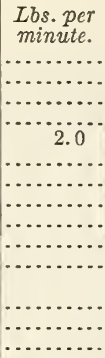 & $\begin{array}{l}\text { Seepage through pores; leak at joints of head. } \\
\text { Head bulged flush with chime. } \\
\text { Leak between staves at bilge. } \\
\text { Test discontinued. } \\
\text { Leak between staves at chime. } \\
\text { Seepage through pores. } \\
\text { Leak between staves at quarter. } \\
\text { Head bulged flush with chime. } \\
\text { Ieak at joints of head; leak between staves at } \\
\text { bilge. } \\
\text { Head breaking. } \\
\text { Head broke out. }\end{array}$ \\
\hline
\end{tabular}

TABLE 7.-Individual tests-Made-up barrels.

INTERNAL-PRESSURE TESTS.

\begin{tabular}{|c|c|c|c|c|c|}
\hline \multirow[t]{2}{*}{$\begin{array}{l}\text { No of } \\
\text { barrel. }\end{array}$} & $\begin{array}{r}\text { Num- } \\
\text { ber of } \\
\text { hoops. } \\
\\
8\end{array}$ & $\begin{array}{c}\begin{array}{l}\text { Pres- } \\
\text { sure. }\end{array} \\
\text { Lbs.per }\end{array}$ & \multicolumn{2}{|c|}{ Rate of leakage. } & Remarks. \\
\hline & 8 & $\begin{array}{c}\text { Lbs. per } \\
\text { sq. in. } \\
4 \\
10 \\
14 \\
16 \\
22 \\
26 \\
32 \\
34 \\
4 \\
6 \\
12 \\
18 \\
24 \\
26 \text { to } 36 \\
38\end{array}$ & 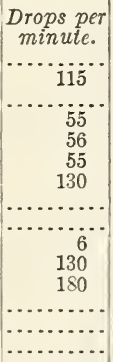 & 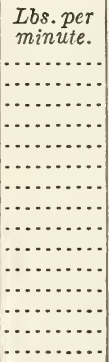 & $\begin{array}{l}\text { Leak through defective joint in head. } \\
\text { Leak at defective joint ceasing. } \\
\text { Head bulged flush with chime. } \\
\text { Head split at joint. } \\
\text { Seepage through pores. } \\
\text { Leak at chime. } \\
\text { Head bulged flush with chime. } \\
\text { Leaking in broken stream. } \\
\text { Head forced out. }\end{array}$ \\
\hline
\end{tabular}

DROP TESTS.

\begin{tabular}{|c|c|c|c|c|}
\hline $\begin{array}{l}\text { No. of } \\
\text { barrel. }\end{array}$ & $\begin{array}{l}\text { Num- } \\
\text { ber of } \\
\text { hoops. }\end{array}$ & $\begin{array}{l}\text { Height } \\
\text { of drop. }\end{array}$ & $\begin{array}{l}\text { Rate of } \\
\text { leakage. }\end{array}$ & Remarks. \\
\hline \multicolumn{5}{|r|}{ SIDE DROP. } \\
\hline & 8 & $\begin{array}{c}\text { Inches. } \\
12 \\
18 \\
21 \\
33\end{array}$ & \begin{tabular}{c}
$\begin{array}{c}\text { Lbs. per } \\
\text { minute. }\end{array}$ \\
\hdashline$\ldots .$. \\
\hdashline \\
\hdashline \\
21.0
\end{tabular} & $\begin{array}{l}\text { Leak at chime; stave slips. } \\
\text { Stare cracked. } \\
\text { Hoop slips. } \\
\text { Two broken staves. }\end{array}$ \\
\hline \multicolumn{5}{|r|}{ DIAGONAL DROP. } \\
\hline & 8 & $\begin{array}{r}9 \\
12 \\
18 \\
21\end{array}$ & … & $\begin{array}{l}\text { Leak at chime. } \\
\text { Stave slips. } \\
\text { Head failing. } \\
\text { Head broke out. }\end{array}$ \\
\hline
\end{tabular}


ADDITIONAL COPIES

OF THIS PUBLICATION MAY BE PROCURED FROME THE SUPERINTENDENT OF DOCUMENTS

GOVERNMENT PRINTING OFFICE

WASHINGTON, D. C.

$\Delta T$

5 CENTS PER COPY

$\nabla$ 

- 





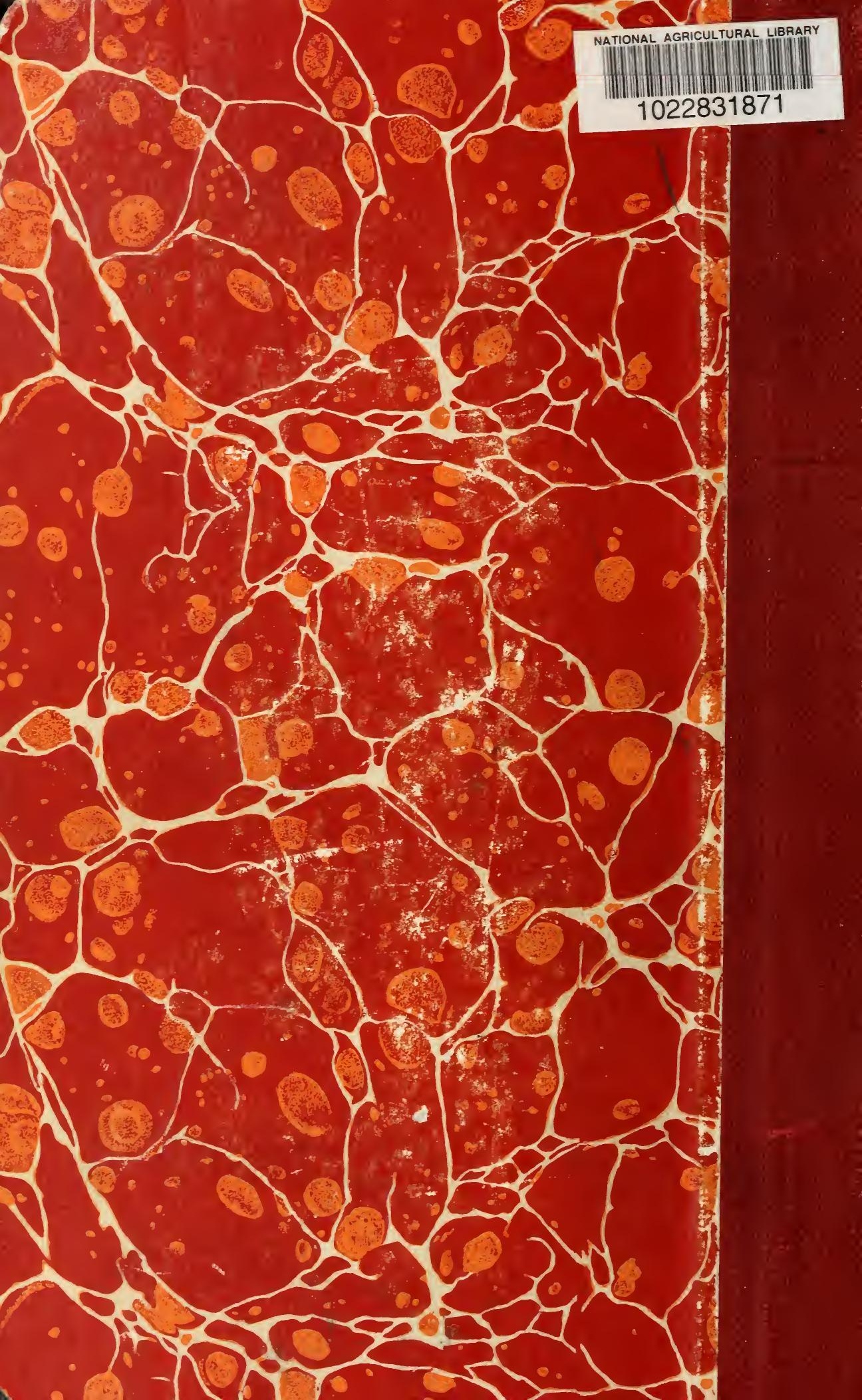

